\title{
Palladium-Catalysed Coupling and Acid-Mediated Cyclisation: Synthesis of Fluorenones and Fluorenes
}

\author{
Devarapalli Ravi Kumar ${ }^{(\mathbb{C}}$ \\ Dakoju Ravi Kishore \\ Gedu Satyanarayana*
}

Department of Chemistry, Indian Institute of Technology Hyderabad, Kandi - 502 285, Sangareddy, Telangana, India gvsatya@iith.ac.in

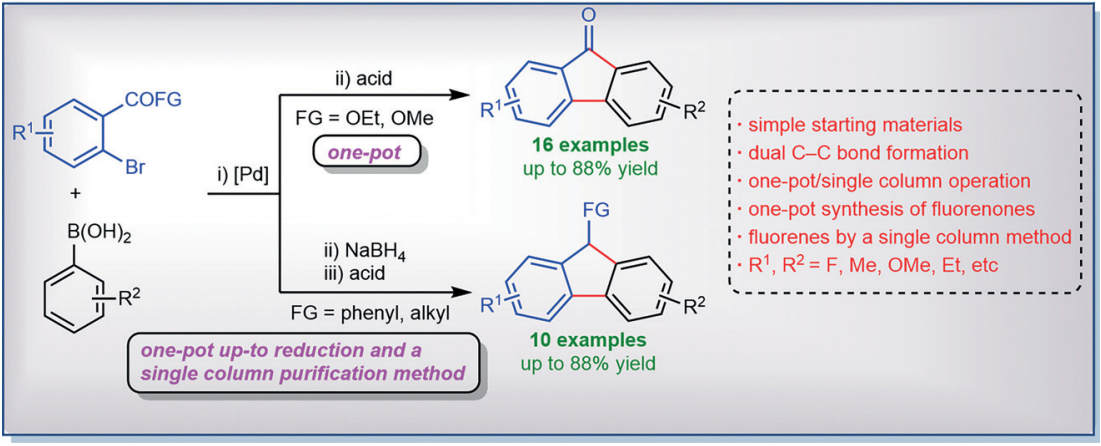

Received: 18.07.2018

Accepted after revision: 16.09 .2018

Published online: 30.10 .2018

DOI: 10.1055/s-0037-1610663; Art ID: so-2018-d0043-op

License terms: cc)

Abstract Palladium-catalysed sequential one-pot synthesis of fluorenones is described. The reaction comprises intermolecular Suzuki coupling and intramolecular acid-mediated cyclisation in a one-pot procedure. The protocol is also applied to the synthesis of fluorenes using a single column purification.

Key words Friedel-Crafts, cyclocarbonylation, fluorenone, fluorine

One-pot or sequential one-pot strategies enhance synthetic efficiency and enable access to diversified molecules. ${ }^{1}$ Fluorenones comprise fused tricyclic frameworks of biological and pharmaceutical significance, ${ }^{2}$ through scavenging of redundant radicals in the body. ${ }^{3}$ Significantly, the fluorenone core constitutes a complete carbon skeleton in certain natural products. ${ }^{3,4}$ As a result of interest in developing new synthetic strategies for the preparation of fluorenones, some interesting approaches have been established. ${ }^{5}$ Conventional synthetic paths for the preparation of fluorenones involve Friedel-Crafts ring closure of biarylcarboxylic acids and the oxidation of fluorenes, ${ }^{6}$ which usually involves several synthetic steps. Other methods for the synthesis of fluorenones include radical cyclisation, ${ }^{7}$ transition-metal catalysed ring closure of benzophenones and biphenyl-2-carbonitrile, ${ }^{8}$ and cyclocarbonylation of 2-halobiaryls. ${ }^{9}$ In particular, Hilt and co-workers have synthesised fluorenones by using an intramolecular Friedel-Crafts acylation of biphenyl 2-carboxylic acid esters. ${ }^{10}$

Functionalised fluorenes are useful materials for optical brightening agents, dyes and ligands in organometallic chemistry. ${ }^{11}$ Similar to fluorenones, conventional approaches for the synthesis of fluorenes are also mostly based on multistep approaches. For example, Jana et al. prepared flu- orenes from 2-phenylbenzyl alcohols by using a Lewis acid mediated Friedel-Crafts reaction as the key reaction. ${ }^{12}$ Wang et al. accomplished the synthesis of fluorenes from $\mathrm{N}$-tosylhydrazones by a carbene aromatic substitution reaction. ${ }^{13}$ The research group of Sarkar has described the preparation of fluorenes from ortho-bromobenzaldehydes in a two-step process. ${ }^{14}$

Although the established methodologies that are used to synthesise fluorenones are effective, they are stepwise and require advanced synthetic precursors. Therefore, there is scope for the development new protocols, particularly one-pot versions. To our knowledge, there are no reports on the synthesis of fluorenones using a one-pot process and simple starting materials. Based on our interest in the development of one-pot or sequential one-pot processes, ${ }^{15}$ we have recently presented a synthesis of fluorenones from benzylamines and iodoarenes, under palladium-catalysed functional group-directing triple ortho- $\mathrm{C}-\mathrm{H}$ activation. ${ }^{16 a}$ More recently, we described the synthesis of fluorenones via Suzuki coupling and subsequent oxidative cyclisation in a sequential one-pot manner. ${ }^{16 b}$ Herein, we present a onepot approach to the synthesis of fluorenones through palladium-catalysed coupling of ortho-bromobenzoic acid esters and arylboronic acids and subsequent intramolecular Friedel-Crafts acylation. Furthermore, the strategy was applied to the synthesis of fluorenes by using the same strategy, with a single column purification.

To begin with, it was anticipated that fluorenone 4aa could be obtained in a sequential one-pot operation by employing an intramolecular Friedel-Crafts acylation of the Suzuki product biphenyl ester 3aa generated in situ (Table 1). Based on our earlier achievements in the synthesis of indanones ${ }^{17}$ and dihydrocoumarins, ${ }^{18}$ it was conceived that Friedel-Crafts acylation in situ of relatively inert biphenyl ester 3aa could only be feasible in the presence of a 
sufficiently strong acid. Furthermore, to promote in situ acylation in a one-pot protocol, some acid will be sacrificed to quench the base used for the initial Suzuki coupling step.

Thus, the screening study was initiated with 2-bromoethyl benzoate 1a and phenylboronic acid 2a. Suzuki coupling was performed in the presence of $\operatorname{Pd}(\mathrm{OAc})_{2}(5$ mol\%) and $\mathrm{K}_{2} \mathrm{CO}_{3}$ (2 equiv) in various solvents, at $80{ }^{\circ} \mathrm{C}$ for 15 to $24 \mathrm{~h}$ (Table 1, entries 1-15). After confirming the formation of Suzuki product 3aa, by TLC, the subsequent Friedel-Crafts acylation to give the desired fluorenone 4aa was carried out by the addition of different acids to the reaction mixture at room temperature and the resultant reaction mixture was again heated $\left(80^{\circ} \mathrm{C}\right.$ or $\left.100{ }^{\circ} \mathrm{C}\right)$. Thus, treatment with conc. sulfuric acid at $100{ }^{\circ} \mathrm{C}$ for $5 \mathrm{~h}$, gave fluorenone 4aa in trace amounts (entry 1) and TfOH at $100{ }^{\circ} \mathrm{C}$ gave a similar result (entry 2 ). A slight improvement was observed when conc. sulfuric acid was added to the Suzuki product in $\mathrm{N}, \mathrm{N}$-dimethylformamide (DMF) (entries 3 and 4); whereas fluorenone 4aa was obtained in moderate yield when 3aa in DMF was reacted with TfOH (entry 5). The reaction was inferior when TfOH was added to 3aa in a 1:1 mixture of DMF and $\mathrm{H}_{2} \mathrm{O}$ (entry 6 ) and there was no reaction with $\mathrm{TfOH}$ in $\mathrm{CH}_{3} \mathrm{CN}$ or DMSO (entries 7 and 8). Since most of such acid mediated reactions have been carried out in halogenated solvents, we decided to carry out both reactions in 1,2-dichloroethane (DCE).$^{19}$ Therefore, to the biaryl Suzuki product 3aa formed in DCE, TfOH was added and the mixture was heated at $80^{\circ} \mathrm{C}$, giving the desired product fluorenone 4aa in $58 \%$ yield (entry 9). Acylation with conc. sulfuric acid in DCE gave 4aa in 54\% yield (entry 10). On the other hand, acylation with the addition of TfOH in $\mathrm{CH}_{2} \mathrm{Cl}_{2}$ furnished 4aa in moderate yield (entry 11). Gratifyingly, treatment of 3aa in DCE with 10 equiv of TfOH raised the yield to $68 \%$ (entry 12). On the contrary, when the amount of TfOH was further increased to 15 equiv, the yield of 4aa decreased to $40 \%$ (entry 13). Finally, reaction in DCE, with $\mathrm{BF}_{3} \cdot \mathrm{OEt}_{2}$ or $\mathrm{AlCl}_{3}$ furnished 4aa in inferior yields (entries 14 and 15).

With the above optimized conditions established for the formation of 4aa (Table 1, entry 12), the one-pot process was examined with other 2-bromobenzoic acid esters 1a-e and phenylboronic acids $\mathbf{2 a - g}$. Gratifyingly, the process proved to be generally applicable and delivered fluorenones 4aa-ff (Scheme 1). In addition to ethyl 2-bromobenzoate, the protocol occurred smoothly with ortho-bromobenzoic acid esters bearing Me (1) b), OMe (1c and $\mathbf{1 d}$ ) and even electron deactivating $\mathrm{F}(\mathbf{1 e})$ on the aromatic ring (Scheme 1). The reaction was also compatible with different arylboronic acids $2 \mathbf{2}-\mathbf{g}$. Thus, the strategy was successful with paramethyl and para-ethylphenylboronic acids $2 \mathbf{d}$ and $\mathbf{2 e}$ (4ae, 4be, 4cd, 4ce, 4dd, 4de and 4ed, Scheme 1) and with electron-rich arylboronic acids such as $\mathbf{2 f}$ and $\mathbf{2 g}$ (4af, $\mathbf{4 b g}, \mathbf{4 c f}$, $\mathbf{4 c g}, \mathbf{4 d f}$ and 4 ef, Scheme 1). Significantly, the protocol was also successful with an arylboronic acid $(\mathbf{2 c})$ bearing an
Table 1 Optimisation Study for the Formation of Fluorenone 4aa

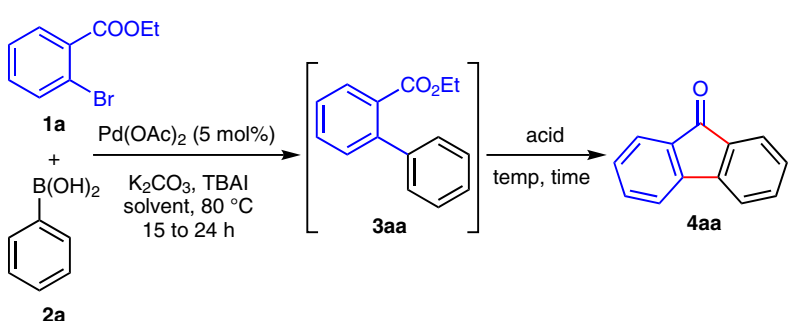

2a

\begin{tabular}{|c|c|c|c|c|c|}
\hline Entry & Solvent (2 mL) & Acid $^{b}$ & Temp $\left({ }^{\circ} \mathrm{C}\right)$ & Time (h) & Yield 4aa (\%) \\
\hline 1 & $\mathrm{H}_{2} \mathrm{O}$ & $\mathrm{H}_{2} \mathrm{SO}_{4}$ & 100 & 5 & trace $^{\mathrm{d}}$ \\
\hline 2 & $\mathrm{H}_{2} \mathrm{O}$ & $\mathrm{TfOH}$ & 100 & 5 & trace $^{\mathrm{d}}$ \\
\hline 3 & DMF & $\mathrm{H}_{2} \mathrm{SO}_{4}$ & 100 & 5 & 20 \\
\hline 4 & DMF & $\mathrm{H}_{2} \mathrm{SO}_{4}$ & 100 & 10 & 23 \\
\hline 5 & DMF & $\mathrm{TfOH}$ & 100 & 10 & 40 \\
\hline 6 & $\mathrm{DMF}+\mathrm{H}_{2} \mathrm{O}(1: 1)$ & $\mathrm{TfOH}$ & 100 & 10 & trace $^{\mathrm{d}}$ \\
\hline 7 & $\mathrm{CH}_{3} \mathrm{CN}$ & $\mathrm{TfOH}$ & 100 & 10 & trace $^{d}$ \\
\hline 8 & DMSO & $\mathrm{TfOH}$ & 100 & 10 & trace $^{d}$ \\
\hline 9 & DCE & $\mathrm{TfOH}$ & 80 & 10 & 58 \\
\hline 10 & DCE & $\mathrm{H}_{2} \mathrm{SO}_{4}$ & 80 & 10 & 54 \\
\hline 11 & $\mathrm{CH}_{2} \mathrm{Cl}_{2}$ & TfOH & 100 & 10 & 43 \\
\hline 12 & DCE & TfOH & 80 & 10 & $68^{e}$ \\
\hline 13 & DCE & $\mathrm{TfOH}$ & 80 & 10 & $40^{f}$ \\
\hline 14 & DCE & $\mathrm{BF}_{3} \cdot \mathrm{OEt}_{2}$ & 80 & 10 & trace $^{\mathrm{d}}$ \\
\hline 15 & DCE & $\mathrm{AlCl}_{3}$ & 80 & 10 & trace $^{d}$ \\
\hline
\end{tabular}

a Unless otherwise mentioned, all the reactions were carried out using 2-bro moethyl benzoate $1 \mathbf{a}(0.50 \mathrm{mmol})$, phenylboronic acid $\mathbf{2 a}(0.55 \mathrm{mmol}), \mathrm{K}_{2}-$ $\mathrm{CO}_{3}(1.0 \mathrm{mmol})$, acid $(5 \mathrm{mmol}), \operatorname{Pd}(\mathrm{OAC})_{2}(5 \mathrm{~mol} \%)$, TBAl $(16 \mathrm{mg}, 10 \mathrm{~mol} \%)$ in a screw-cap vial.

${ }^{\mathrm{b}}$ Acid (5 equiv) was used.

c Isolated yields of chromatographically pure products.

d Only a trace amount of product was formed.

e TfOH ( 10 equiv) was used.

${ }^{\mathrm{T}} \mathrm{TfOH}$ ( 15 equiv) has been used.

electron-deactivating functional group (4dc, Scheme 1). Thus, this strategy shows a good substrate scope and furnishes a variety of fluorenones.

After the successful synthesis of fluorenones, we turned our attention to the synthesis of fluorenes. For this purpose, it was conceived that biaryl secondary alcohols would serve as ideal precursors for fluorenes. Based on our previous sequential one-pot protocols of palladium-catalysed Heck reaction and subsequent reduction of the carbonyl group, ${ }^{20} \mathrm{a}$ sequential one-pot Suzuki coupling and reduction sequence in a one-pot strategy was considered. Thus, intramolecular Friedel-Crafts alkylation reaction of biaryl secondary alcohols would generate the desired fluorenes. Since a polar solvent is required for smooth reduction of the carbonyl group of the Suzuki product, in this case the reaction between ortho-bromoacetophenone $\mathbf{5 a}$ and para-tolylboronic acid $\mathbf{2 a}$ 


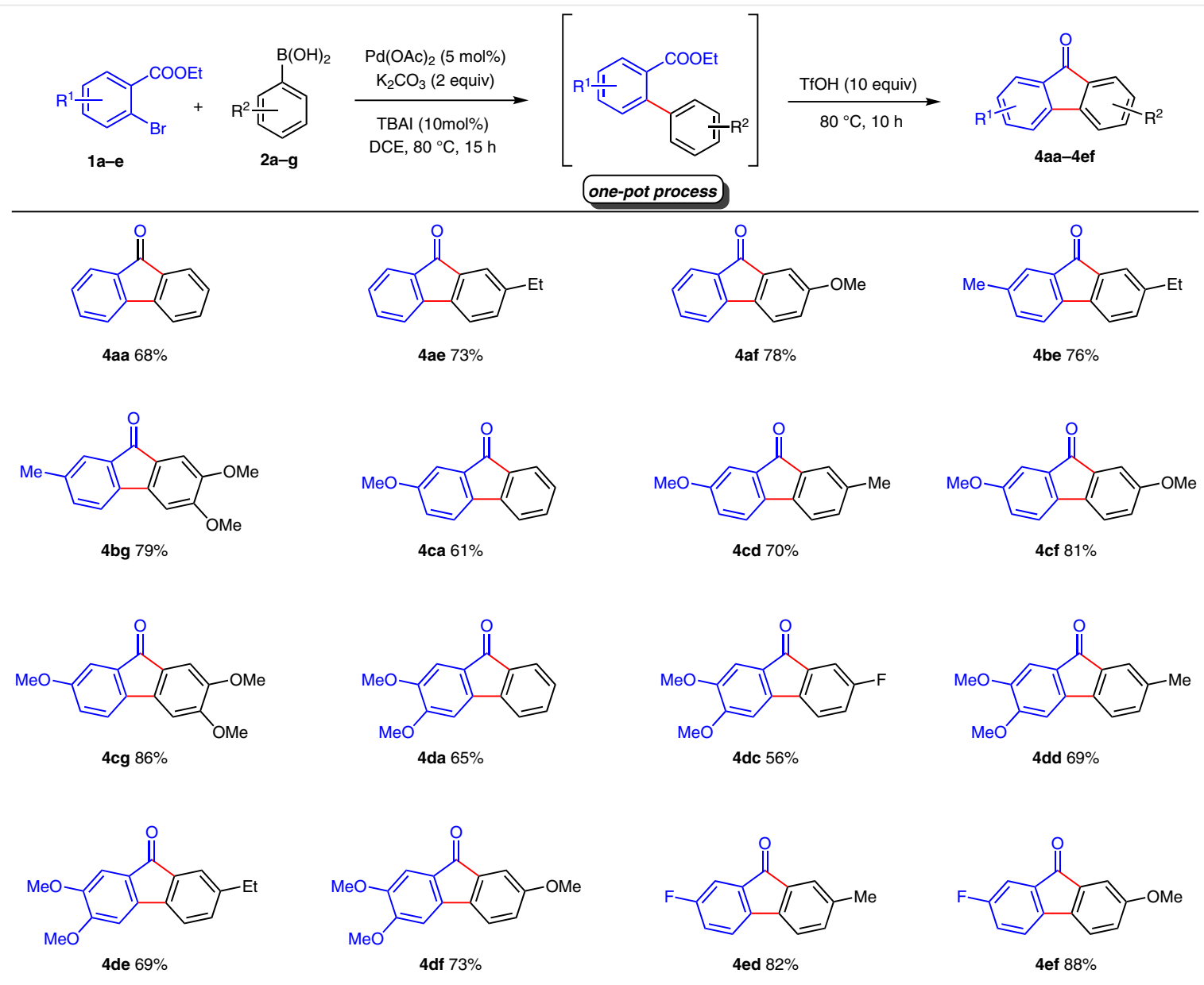

Scheme 1 Synthesis of fluorenones $\mathbf{4 a a - e f}$ from $\mathbf{1 a}-\mathbf{e}$ and $\mathbf{2 a - g}$. Reaction conditions: 2-bromoethyl benzoate $\mathbf{1 a}-\mathbf{e}(0.5 \mathrm{mmol})$, arylboronic acid $\mathbf{2 a -}$ g $(0.55 \mathrm{mmol}), \operatorname{Pd}(\mathrm{OAC})_{2}(6 \mathrm{mg}, 5 \mathrm{~mol} \%), \mathrm{K}_{2} \mathrm{CO}_{3}(138 \mathrm{mg}, 1.0 \mathrm{mmol}), \mathrm{TBAl}(16 \mathrm{mg}, 10 \mathrm{~mol} \%), \mathrm{DCE}(2 \mathrm{~mL}), 100^{\circ} \mathrm{C}, 15 \mathrm{~h}$. After confirming formation of the Suzuki product, $\mathrm{TfOH}$ (10 equiv) was added at $0{ }^{\circ} \mathrm{C}$ and the mixture was stirred at room temperature. Yields in parentheses are isolated yields of chromatographically pure products.

was conducted in DNF in the presence of $\mathrm{Pd}(\mathrm{OAc})_{2}(5 \mathrm{~mol} \%)$ and $\mathrm{K}_{2} \mathrm{CO}_{3}$ (2 equiv) at $80{ }^{\circ} \mathrm{C}$ for $24 \mathrm{~h}$. After confirming formation of the Suzuki product 6aa, by TLC, the cooled reaction mixture was then subjected to reduction with $\mathrm{NaBH}_{4}$ in situ, at $0{ }^{\circ} \mathrm{C}$ to r.t., for $30 \mathrm{~min}$. After work-up, the crude biaryl secondary alcohol 7aa was then treated with mild Lewis acid $\mathrm{BF}_{3} \cdot \mathrm{OEt}_{2}$ in DCE, $0{ }^{\circ} \mathrm{C}$ to r.t., and fluorene 8aa was isolated in $77 \%$ overall yield after column chromatography (Scheme 2). With these established conditions, the procedure was extended to the synthesis of a range of fluorenes derived from ortho-bromoacetophenones $\mathbf{5 a - f}$ and arylboronic acids 2a-g, furnishing fluorenes 8ad-eg (Scheme 2).

In conclusion, we have established a sequential one-pot strategy for the synthesis of fluorenones. Palladium-catalysed Suzuki coupling and acid-mediated intramolecular Friedel-Crafts acylation were employed in the one-pot pro- tocol. In addition, Suzuki coupling, followed by reduction and intramolecular Friedel-Crafts alkylation in a one-pot protocol has been developed for the synthesis of fluorenes.

IR spectra were recorded with a Bruker Tensor 37 (FTIR) spectrophotometer. ${ }^{1} \mathrm{H}$ NMR spectra were recorded with a Bruker Avance 400 (400 MHz) spectrometer in $\mathrm{CDCl}_{3}$; chemical shifts $(\delta$, ppm) and coupling constants $(\mathrm{Hz})$ are reported with reference to either internal standard tetramethylsilane (TMS) $\left(\delta_{\mathrm{H}}=0.00 \mathrm{ppm}\right)$ or $\mathrm{CHCl}_{3}\left(\delta_{\mathrm{H}}=7.25\right.$ $\mathrm{ppm}) .{ }^{13} \mathrm{C}$ NMR spectra were recorded with a Bruker Avance 400 (100 $\mathrm{MHz}$ ) spectrometer in $\mathrm{CDCl}_{3}$; chemical shifts $(\delta$, ppm) are reported relative to $\mathrm{CHCl}_{3}\left[\delta_{\mathrm{C}}=77.00 \mathrm{ppm}\right.$ (central line of triplet)]. In the ${ }^{13} \mathrm{C}$ NMR spectra, the nature of carbons $\left(\mathrm{C}, \mathrm{CH}, \mathrm{CH}_{2}\right.$ and $\left.\mathrm{CH}_{3}\right)$ was determined by recording the DEPT- 135 spectra, and given in parentheses as $\mathrm{s}=\operatorname{singlet}\left(\right.$ for $\mathrm{C}$ ), $\mathrm{d}=\operatorname{doublet}\left(\right.$ for $\mathrm{CH}$ ), $\mathrm{t}=$ triplet $\left(\right.$ for $\mathrm{CH}_{2}$ ) and $\mathrm{q}=$ quartet (for $\mathrm{CH}_{3}$ ). In the ${ }^{1} \mathrm{H}$ NMR spectra, the following abbreviations are used throughout: $\mathrm{s}=$ singlet, $\mathrm{d}=$ doublet, $\mathrm{t}=$ triplet, $\mathrm{q}=$ quartet, qui $=$ quin, sept $=$ sept, $\mathrm{dd}=$ doublet of doublets, $\mathrm{m}=$ multiplet and $\mathrm{br}$. 


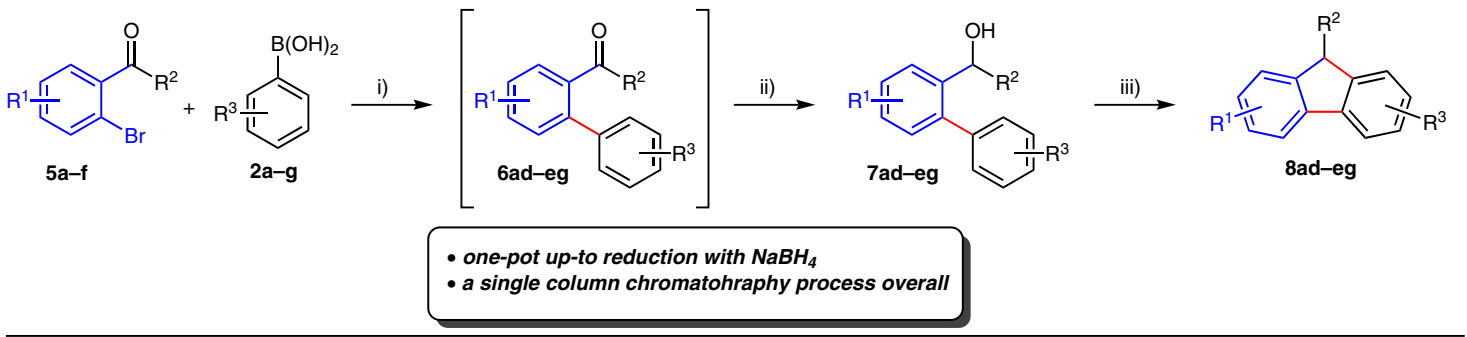<smiles>Cc1ccc2c(c1)C(C)c1ccccc1-2</smiles>

8ad $77 \%$<smiles>COc1ccc2c(c1)C(C)c1cc(OC)c(OC)cc1-2</smiles>

8bg $85 \%$<smiles>COc1ccc2c(c1)C(c1ccccc1)c1ccccc1-2</smiles>

8ef $79 \%$<smiles>CCc1ccc2c(c1)C(C)c1ccccc1-2</smiles>

8ae $85 \%$<smiles>CCC1c2cc(OC)ccc2-c2cc(OC)c(OC)cc21</smiles>

8 cf $72 \%$<smiles>COc1cc2c(cc1OC)C(C)c1ccccc1-2</smiles>

8ag $82 \%$<smiles>Cc1ccc2c(c1)C(c1ccccc1)c1ccccc1-2</smiles>

8ed $81 \%$<smiles>COc1ccc2c(c1)C(C)c1cc(OC)ccc1-2</smiles>

8bf $82 \%$<smiles>CCc1ccc2c(c1)C(c1ccccc1)c1ccccc1-2</smiles>

8 ee $67 \%$

Scheme 2 Synthesis of fluorenes 8 ad-eg from $\mathbf{2 a}-\mathbf{g}$ and $\mathbf{5 a}-\mathbf{f}$. Reaction conditions: (i) Pd(OAc) $2, \mathrm{TBAl} \mathrm{K}_{2} \mathrm{CO}_{3}, \mathrm{DMF}, 80^{\circ} \mathrm{C}, 24 \mathrm{~h}$; (ii) $\mathrm{NaBH} 4,0{ }^{\circ} \mathrm{C}$ to r.t., $0.5 \mathrm{~h}$; (iii) $\mathrm{BF}_{3} \cdot \mathrm{OEt}_{2}, \mathrm{DCE}(2 \mathrm{~mL}), 0{ }^{\circ} \mathrm{C}$ to r.t. Reactions were performed with 2-bromo ketones $5 \mathbf{a}-\mathbf{e}(0.5 \mathrm{mmol})$, arylboronic acid $\mathbf{2 a}-\mathbf{g}(0.55 \mathrm{mmol})$, $\mathrm{Pd}(\mathrm{OAC})_{2}(5.6 \mathrm{mg}, 5 \mathrm{~mol} \%), \mathrm{K}_{2} \mathrm{CO}_{3}(138 \mathrm{mg}, 1.0 \mathrm{mmol}), \mathrm{TBAl}(16 \mathrm{mg}, 10 \mathrm{~mol} \%), \mathrm{DCE}(2 \mathrm{~mL}), 100{ }^{\circ} \mathrm{C}, 15 \mathrm{~h}$, after confirming formation of the Suzuki product, $\mathrm{NaBH}_{4}(37.8 \mathrm{mg}, 1.0 \mathrm{mmol})$ was added at $0{ }^{\circ} \mathrm{C}$ then the reaction mixture was stirred at room temperature for $0.5 \mathrm{~h}$. After confirming formation of the corresponding alcohol, $\mathrm{BF}_{3} \cdot \mathrm{OEt}_{2}$ was added to the worked up reaction mixture. Yields in the parentheses are isolated yields of chromatographically pure products.

$\mathrm{S}=$ broad singlet. The assignment of signals was confirmed by ${ }^{1} \mathrm{H},{ }^{13} \mathrm{C}$ carbon-proton decoupling and DEPT spectroscopy. High-resolution mass spectra (HRMS) were recorded with an Agilent 6538 UHD Q-TOF under electrospray ionisation (ESI) mode and atmospheric pressure chemical ionisation (APCI) mode. All small-scale anhydrous reactions were carried out using Schlenk tubes under an inert atmosphere. Reactions were monitored by TLC on silica gel using a combination of hexane and EtOAc as eluent. Reactions were generally run under argon or nitrogen atmosphere. Solvents were distilled prior to use; petroleum ether with a boiling range of 60 to $80^{\circ} \mathrm{C}$ was used. Palladium acetate, potassium carbonate, TBAI, TfOH, $\mathrm{NaBH}_{4}$ and $\mathrm{BF}_{3} \cdot \mathrm{OEt}_{2}$ were purchased from Sigma-Aldrich and used as received. 2-Bromoethyl benzoates were used as received. 2-Bromoaryl ketones were prepared from 2-bromobenzaldehydes by using standard Grignard and oxidation protocol. Acme silica gel (60-120 mesh) was used for column chromatography (ca. $20 \mathrm{~g}$ per gram of crude material). ${ }^{15}$

\section{Synthesis of Fluorenones 4; General Procedure}

In an oven-dried Schlenk tube, were added ethyl 2-bromobenzoate $\mathbf{1}$ (114-145 mg, $0.5 \mathrm{mmol}$ ), phenylboronic acid 2 (122-182 mg, 0.55 $\mathrm{mmol}$ ), palladium acetate ( $5.6 \mathrm{mg}, 5 \mathrm{~mol} \%$ ), potassium carbonate (138 $\mathrm{mg}, 1.0 \mathrm{mmol}$ ) and TBAI (16 $\mathrm{mg}, 10 \mathrm{~mol} \%)$ followed by DCE $(2.0 \mathrm{~mL})$ at r.t. and the reaction mixture was stirred at $80^{\circ} \mathrm{C}$ for $15 \mathrm{~h}$. Progress of the reaction for the formation of Suzuki product was monitored by TLC until completion of reaction. The mixture was then cooled to r.t., TfOH (375 mg, $10 \mathrm{mmol}$ ) was added and the mixture was stirred at $80{ }^{\circ} \mathrm{C}$ for $10 \mathrm{~h}$. Progress of the reaction for the formation of fluorenone 4 was monitored by TLC. On completion, the reaction was quenched with aq. $\mathrm{NaHCO}_{3}$ then diluted with aq. $\mathrm{NH}_{4} \mathrm{Cl}$ solution and extracted with EtOAc $(3 \times 20 \mathrm{~mL})$. The combined organic layers were washed with saturated $\mathrm{NaCl}$ solution, dried $\left(\mathrm{Na}_{2} \mathrm{SO}_{4}\right)$, and filtered. Evaporation of the solvent under reduced pressure and purification of the crude material by silica gel column chromatography (petroleum ether/EtOAc) furnished the fluorenone 4 (56 to 88\%), as semi-sol$\mathrm{id} /$ solid products. Some of the fluorenones have been reported in the literature. $5,6,16,21$

\section{Synthesis of Fluorenes 8; General Procedure}

In an oven-dried Schlenk tube, were added 2-bromophenylketone $\mathbf{5}$ (100-137 mg, $0.5 \mathrm{mmol}$ ), phenylboronic acid 2 (122-182 mg, 0.55 $\mathrm{mmol}$ ), palladium acetate $(5.6 \mathrm{mg}, 5 \mathrm{~mol} \%$ ) and potassium carbonate (138 $\mathrm{mg}, 1.0 \mathrm{mmol}$ ), followed by $\operatorname{DMF}(2.0 \mathrm{~mL})$ at r.t. and the reaction 
mixture was stirred at $80^{\circ} \mathrm{C}$ for $20 \mathrm{~h}$. Progress of formation of the Suzuki product was monitored by TLC, then the mixture was cooled to r.t. To the reaction mixture was added $\mathrm{NaBH}_{4}(76 \mathrm{mg}, 2 \mathrm{mmol})$ at $0{ }^{\circ} \mathrm{C}$ and stirring was continued at r.t. for $0.5 \mathrm{~h}$ and formation of alcohol 7 was monitored by TLC. After work-up, to the crude reaction mixture were added DCE $(2 \mathrm{~mL})$ and $\mathrm{BF}_{3} \cdot \mathrm{OEt}_{2}(710 \mathrm{mg}, 5 \mathrm{mmol})$ at ice temperature and the mixture was stirred at the same temperature for $1 \mathrm{~h}$. Progress of the reaction for the formation of fluorene $\mathbf{8}$ was monitored by TLC. The reaction mixture was quenched with aq. $\mathrm{NaHCO}_{3}$ then diluted with aq. $\mathrm{NH}_{4} \mathrm{Cl}$ and extracted with EtOAc $(3 \times 10 \mathrm{~mL})$. The combined organic layers were washed with saturated aq. $\mathrm{NaCl}$, dried $\left(\mathrm{Na}_{2} \mathrm{SO}_{4}\right)$, and filtered. Evaporation of the solvent under reduced pressure and purification of the crude material by silica gel column chromatography (petroleum ether/EtOAc) furnished fluorenes 8 (67 to $88 \%$ ), as semi-solid/solid products. Several of the fluorenes are already reported in the literature. , $, 6,14,21^{2}$

\section{2-Ethyl-7-methyl-9H-fluoren-9-one (4be)}

In an oven-dried Schlenk tube, were added 2-ethyl 2-bromobenzoate 1b $(121.5 \mathrm{mg}, 0.5 \mathrm{mmol})$, arylboronic acid $2 \mathrm{e}(83 \mathrm{mg}, 0.55 \mathrm{mmol})$, $\mathrm{Pd}(\mathrm{OAc})_{2}$ (5.6 mg, $\left.5 \mathrm{~mol} \%\right), \mathrm{K}_{2} \mathrm{CO}_{3}(138 \mathrm{mg}, 1.0 \mathrm{mmol})$ and TBAI (16 $\mathrm{mg}, 10 \mathrm{~mol} \%)$ followed by DCE $(2.0 \mathrm{~mL})$ at r.t. and the reaction mixture was stirred at $80^{\circ} \mathrm{C}$ for $20 \mathrm{~h}$. To the cooled reaction mixture at r.t., was added TfOH (755 mg, $5.0 \mathrm{mmol}$ ) and stirring was continued at $80^{\circ} \mathrm{C}$ for $15 \mathrm{~h}$. Purification of the crude material by silica gel column chromatography (petroleum ether/EtOAc, 99:1 to 95:5) furnished 4 be.

Yield: $84.4 \mathrm{mg}$ (76\%); yellow solid; TLC (petroleum ether/EtOAc 95:05; UV detection): $R_{f}=0.8$ (1b), 0.6 (4be).

${ }^{1} \mathrm{H} \mathrm{NMR}\left(\mathrm{CDCl}_{3}, 400 \mathrm{MHz}\right): \delta=7.46(\mathrm{~d}, J=0.9 \mathrm{~Hz}, 1 \mathrm{H}, \mathrm{Ar}-\mathrm{H}), 7.42(\mathrm{~s}$, $1 \mathrm{H}, \mathrm{Ar}-\mathrm{H}), 7.34$ (d, J = 7.3 Hz, $1 \mathrm{H}, \mathrm{Ar}-\mathrm{H}), 7.32(\mathrm{~d}, J=7.2 \mathrm{~Hz}, 1 \mathrm{H}, \mathrm{Ar}-\mathrm{H})$, 7.29-7.18 (m, $2 \mathrm{H}, \mathrm{Ar}-\mathrm{H}$ ), 2.64 (q, $\left.2 \mathrm{H}, J=7.7 \mathrm{~Hz}, \mathrm{CH}_{2} \mathrm{CH}_{3}\right), 2.34(\mathrm{~s}, 3 \mathrm{H}$, $\left.\mathrm{Ar}-\mathrm{CH}_{3}\right), 1.23\left(\mathrm{t}, 3 \mathrm{H}, \mathrm{J}=7.7 \mathrm{~Hz}, \mathrm{CH}_{2} \mathrm{CH}_{3}\right)$.

${ }^{13} \mathrm{C} \mathrm{NMR}\left(\mathrm{CDCl}_{3}, 100 \mathrm{MHz}\right): \delta=194.5$ (s, C=O), $145.2(\mathrm{~s}, \mathrm{Ar}-\mathrm{C}), 142.3$ (s, Ar-C), 142.0 (s, Ar-C), 138.7 (s, Ar-C), 135.0 (d, Ar-CH), 134.6 (s, Ar-C), 134.0 (s, Ar-C), 134.0 (d, Ar-CH), 124.9 (d, Ar-CH), 123.7 (d, Ar-CH), 119.9 (d, Ar-CH), 119.8 (d, Ar-CH), 28.7 (t, $\mathrm{CH}_{2}$ ), 21.3 (q, $\left.\mathrm{ArCH}_{3}\right), 15.3$ (q, $\mathrm{CH}_{3}$ ).

HRMS (APCI+): $m / z[M+H]^{+}$calcd for $\left[\mathrm{C}_{16} \mathrm{H}_{15} \mathrm{O}\right]^{+}:$223.1117; found: 223.1113.

\section{2-Methoxy-7-methyl-9H-fluoren-9-one (4cd)}

In an oven-dried Schlenk tube, were added ethyl 2-bromobenzoate 1c (129.5 mg, $0.5 \mathrm{mmol})$, arylboronic acid $2 \mathrm{~d}(75 \mathrm{mg}, 0.55 \mathrm{mmol})$, $\mathrm{Pd}(\mathrm{OAc})_{2}$ (5.6 mg, $\left.5 \mathrm{~mol} \%\right), \mathrm{K}_{2} \mathrm{CO}_{3}(138 \mathrm{mg}, 1.0 \mathrm{mmol})$ and TBAI (16 $\mathrm{mg}, 10 \mathrm{~mol} \%)$ followed by DCE $(2.0 \mathrm{~mL})$ at r.t. and the reaction mixture was stirred at $80^{\circ} \mathrm{C}$ for $20 \mathrm{~h}$. To the cooled reaction mixture at r.t., was added TfOH (755 mg, $5.0 \mathrm{mmol}$ ) and stirring was continued at $80{ }^{\circ} \mathrm{C}$ for $15 \mathrm{~h}$. Purification of the crude material by silica gel column chromatography (petroleum ether/EtOAc, 99:1 to 95:5) furnished 4cd.

Yield: $78.5 .0 \mathrm{mg}$ (70\%); yellow solid; TLC (petroleum ether/EtOAc 95:05; UV detection): $R_{f}=0.6$ (1c), 0.3 (4cd).

${ }^{1} \mathrm{H} \mathrm{NMR}\left(\mathrm{CDCl}_{3}, 400 \mathrm{MHz}\right): \delta=7.39(\mathrm{~s}, 1 \mathrm{H}, \mathrm{Ar}-\mathrm{H}), 7.32(\mathrm{~d}, J=8.2 \mathrm{~Hz}$, $1 \mathrm{H}, \mathrm{Ar}-\mathrm{H}), 7.25$ (d, J = 7.4 Hz, $1 \mathrm{H}, \mathrm{Ar}-\mathrm{H}), 7.20(\mathrm{~d}, J=8.2 \mathrm{~Hz}, 1 \mathrm{H}, \mathrm{Ar}-\mathrm{H})$, $7.16(\mathrm{~d}, J=2.4 \mathrm{~Hz}, 1 \mathrm{H}, \mathrm{ArH}), 6.94(\mathrm{dd}, J=8.2,2.4 \mathrm{~Hz}, 1 \mathrm{H}, \mathrm{Ar}-\mathrm{H}), 3.83$ (s, $\left.3 \mathrm{H}, \mathrm{ArOCH}_{3}\right), 2.33$ (s, $3 \mathrm{H}, \mathrm{ArCH}_{3}$ ).

${ }^{13} \mathrm{C} \mathrm{NMR}\left(\mathrm{CDCl}_{3}, 100 \mathrm{MHz}\right): \delta=194.1$ (s, C=0), 160.5 (s, $\left.\mathrm{Ar}-\mathrm{C}\right), 142.2(\mathrm{~s}$, $\mathrm{Ar}-\mathrm{C}), 137.9$ (s, Ar-C), $137.2(\mathrm{~s}, \mathrm{Ar}-\mathrm{C}), 136.0$ (s, Ar-C), $135.2(\mathrm{~d}, \mathrm{Ar}-\mathrm{CH})$, 134.6 (s, Ar-C), 125.1 (d, Ar-CH), 121.0 (d, Ar-CH), 120.1 (d, Ar-CH), $119.4(\mathrm{~d}, \mathrm{Ar}-\mathrm{CH}), 109.4$ (d, $\mathrm{Ar}-\mathrm{CH}), 55.7\left(\mathrm{q}, \mathrm{ArOCH}_{3}\right), 55.5\left(\mathrm{q}, \mathrm{ArOCH}_{3}\right)$, $21.2\left(\mathrm{q}, \mathrm{ArCH}_{3}\right)$.
HRMS (APCI+): $m / z[M+H]^{+}$calcd for $\left[\mathrm{C}_{15} \mathrm{H}_{13} \mathrm{O}_{2}\right]^{+}: 225.0910$; found: 225.0890 .

\section{7-Ethyl-2,3-dimethoxy-9H-fluoren-9-one (4de)}

In an oven-dried Schlenk tube, were added ethyl 2-bromobenzoate 1d (144.5 mg, $0.5 \mathrm{mmol}$ ), arylboronic acid $2 \mathrm{e}(83 \mathrm{mg}, 0.55 \mathrm{mmol})$, $\mathrm{Pd}(\mathrm{OAc})_{2}$ (5.6 mg, $\left.5 \mathrm{~mol} \%\right), \mathrm{K}_{2} \mathrm{CO}_{3}(138 \mathrm{mg}, 1.0 \mathrm{mmol}$ ), and TBAI (16 $\mathrm{mg}, 10 \mathrm{~mol} \%)$ followed by DCE $(2.0 \mathrm{~mL})$ at r.t. and the reaction mixture was stirred at $80^{\circ} \mathrm{C}$ for $20 \mathrm{~h}$. To the cooled reaction mixture at r.t., was added TfOH (755 mg, $5.0 \mathrm{mmol}$ ) and stirring was continued at $80^{\circ} \mathrm{C}$ for $15 \mathrm{~h}$. Purification of the crude material by silica gel column chromatography (petroleum ether/EtOAc, 99:1 to 94:6) furnished 4de.

Yield: $92.4 \mathrm{mg}$ (69\%); yellow solid; TLC (petroleum ether/EtOAc, 94:06; UV detection): $R_{f}=0.6$ (1d), 0.5 (4de).

${ }^{1} \mathrm{H} \mathrm{NMR}\left(\mathrm{CDCl}_{3}, 400 \mathrm{MHz}\right): \delta=7.39(\mathrm{~s}, 1 \mathrm{H}, \mathrm{Ar}-\mathrm{H}), 7.26-7.16(\mathrm{~m}, 2 \mathrm{H}$, Ar-H), 7.15 (s, $1 \mathrm{H}, \mathrm{Ar}-\mathrm{H}), 6.94(\mathrm{~s}, 1 \mathrm{H}, \mathrm{Ar}-\mathrm{H}), 3.98$ (s, $\left.3 \mathrm{H}, \mathrm{ArOCH}_{3}\right)$, $3.89\left(\mathrm{~s}, 3 \mathrm{H}, \mathrm{ArOCH}_{3}\right), 2.62\left(\mathrm{q}, J=7.5 \mathrm{~Hz}, 2 \mathrm{H}, \mathrm{CH}_{2} \mathrm{CH}_{3}\right), 1.22(\mathrm{t}$, $\left.J=7.5 \mathrm{~Hz}, 2 \mathrm{H}, \mathrm{CH}_{2} \mathrm{CH}_{3}\right)$.

${ }^{13} \mathrm{C}$ NMR $\left(\mathrm{CDCl}_{3}, 100 \mathrm{MHz}\right): \delta=193.5(\mathrm{C}=0), 154.5(\mathrm{~s}, \mathrm{Ar}-\mathrm{C}), 149.3(\mathrm{~s}$, Ar-C), 144.8 (s, Ar-C), 141.5 (s, Ar-C), 139.8 (s, Ar-C), 135.1 (s, Ar-C), 133.4 (d, Ar-CH), 126.9 (s, Ar-C), 123.4 (d, Ar-CH), 119.0 (d, Ar-CH), 107.1 (d, Ar-CH), 103.2 (d, Ar-CH), 56.3 (q, $\left.\mathrm{ArOCH}_{3}\right), 56.2\left(\mathrm{q}, \mathrm{ArOCH}_{3}\right)$, $28.7\left(\mathrm{t}, \mathrm{CH}_{2}\right), 15.3\left(\mathrm{q}, \mathrm{CH}_{3}\right)$.

HRMS (APCI+): $m / z[M+H]^{+}$calcd for $\left[\mathrm{C}_{17} \mathrm{H}_{17} \mathrm{O}_{3}\right]^{+}: 269.1172$; found: 269.1166.

\section{2-Fluoro-7-methyl-9H-fluoren-9-one (4ed)}

In an oven-dried Schlenk tube, were added ethyl 2-bromobenzoate $\mathbf{1 e}$ (123.5 mg, $0.5 \mathrm{mmol}$ ), arylboronic acid 2d (75 mg, $0.55 \mathrm{mmol}$ ), $\mathrm{Pd}(\mathrm{OAc})_{2}$ (5.6 mg, $\left.5 \mathrm{~mol} \%\right), \mathrm{K}_{2} \mathrm{CO}_{3}(138 \mathrm{mg}, 1.0 \mathrm{mmol}$ ), and TBAI (16 $\mathrm{mg}, 10 \mathrm{~mol} \%)$ followed by DCE $(2.0 \mathrm{~mL})$ at r.t. and the reaction mixture was stirred at $80^{\circ} \mathrm{C}$ for $20 \mathrm{~h}$. To the cooled reaction mixture at r.t., was added TfOH (755 mg, $5.0 \mathrm{mmol}$ ) and stirring was continued at $80{ }^{\circ} \mathrm{C}$ for $15 \mathrm{~h}$. Purification of the crude material by silica gel column chromatography (petroleum ether/EtOAc, 99:1 to 95:5) furnished 4ed.

Yield: $87.0 \mathrm{mg}$ (82\%); yellow solid; TLC (petroleum ether/EtOAc, 95:05; UV detection): $R_{f}=0.8$ (1e), 0.6 (4ed).

${ }^{1} \mathrm{H} \mathrm{NMR}\left(\mathrm{CDCl}_{3}, 400 \mathrm{MHz}\right): \delta=7.43(\mathrm{~s}, 1 \mathrm{H}, \mathrm{Ar}-\mathrm{H}), 7.42-7.36(\mathrm{~m}, 1 \mathrm{H}$, Ar-H), 7.32 (d, $J=7.8 \mathrm{~Hz}, 1 \mathrm{H}, \mathrm{Ar}-\mathrm{H}), 7.32-7.23(\mathrm{~m}, 2 \mathrm{H}, \mathrm{Ar}-\mathrm{H}), 7.11$ (ddd, $J=8.8,8.3,2.4 \mathrm{~Hz}, 1 \mathrm{H}, \mathrm{Ar}-\mathrm{H}), 2.35\left(\mathrm{~s}, 3 \mathrm{H}, \mathrm{ArCH}_{3}\right.$ ).

${ }^{13} \mathrm{C}$ NMR $\left(\mathrm{CDCl}_{3}, 100 \mathrm{MHz}\right): \delta=192.7$ (s, C=0), $163.2(\mathrm{~d}, J=248.7 \mathrm{~Hz}$, Ar-C), 141.3 (s, Ar-C), 140.4 (s, Ar-C), 138.9 (s, Ar-C), 136.3 (d, $J=$ 7.3 Hz, Ar-C), 135.4 (d, Ar-CH), 134.5 (s, Ar-C), 125.3 (d, Ar-CH), 121.1 (d, $J=8.1 \mathrm{~Hz}, \mathrm{Ar}-\mathrm{CH}), 120.7$ (d, $J=23.0 \mathrm{~Hz}, \mathrm{Ar}-\mathrm{CH}), 119.9$ (d, Ar-CH), 111.8 (d, $J=23.0 \mathrm{~Hz}, \mathrm{Ar}-\mathrm{CH}), 21.3\left(\mathrm{~d}, \mathrm{ArCH}_{3}\right)$.

HRMS (APCI+): $m / z[\mathrm{M}+\mathrm{H}]^{+}$calcd for $\left[\mathrm{C}_{14} \mathrm{H}_{10} \mathrm{FO}\right]^{+}: 213.0710$; found: 213.0693 .

\section{2,3-Dimethoxy-9-methyl-9H-fluorene (8ag)}

In an oven-dried Schlenk tube, were added 2-bromophenylketone 5a (100 mg, $0.5 \mathrm{mmol})$, arylboronic acid $2 \mathrm{~g}(100 \mathrm{mg}, 0.55 \mathrm{mmol})$, $\mathrm{Pd}(\mathrm{OAc})_{2}\left(5.6 \mathrm{mg}, 5 \mathrm{~mol} \%\right.$ ) and $\mathrm{K}_{2} \mathrm{CO}_{3}(138 \mathrm{mg}, 1.0 \mathrm{mmol})$ followed by DMF at r.t. and the reaction mixture was stirred at $80^{\circ} \mathrm{C}$ for $20 \mathrm{~h}$. Then, to the cooled reaction mixture at ice temperature, was added $\mathrm{NaBH}_{4}$ (76 mg, $2 \mathrm{mmol}$ ) and stirring was continued at the same temperature for $0.5 \mathrm{~h}$. After work-up, to the crude reaction mixture at ice temperature, were added $\mathrm{DCE}$ and $\mathrm{BF}_{3} \cdot \mathrm{OEt}_{2}(710 \mathrm{mg}, 5 \mathrm{mmol})$ and stirring was continued for $1 \mathrm{~h}$. Progress of the reaction for the formation of 2,3-dimethoxy-9-methyl-9H-fluorene 8ag was monitored by 
TLC. The reaction mixture was then quenched with aq. $\mathrm{NaHCO}_{3}$, and the mixture was diluted with aq. $\mathrm{NH}_{4} \mathrm{Cl}$ and extracted with EtOAc $(3 \times 10 \mathrm{~mL})$. The combined organic layers were washed with saturated aq. $\mathrm{NaCl}$, dried $\left(\mathrm{Na}_{2} \mathrm{SO}_{4}\right)$ and filtered. Evaporation of the solvent under reduced pressure and purification of the crude material by silica gel column chromatography (petroleum ether/EtOAc, 99:1 to 95:5) furnished the product 8ag.

Yield: $100 \mathrm{mg}$ (82\%); white solid; TLC (petroleum ether/EtOAc, 93:07; UV detection): $R_{f}=0.8$ (5a), 0.6 (8ag).

${ }^{1} \mathrm{H} \mathrm{NMR}\left(\mathrm{CDCl}_{3}, 400 \mathrm{MHz}\right): \delta=7.62(\mathrm{~d}, J=7.4 \mathrm{~Hz}, 1 \mathrm{H}, \mathrm{Ar}-\mathrm{H}), 7.44(\mathrm{~d}$, $J=7.3 \mathrm{~Hz}, 1 \mathrm{H}, \mathrm{Ar}-\mathrm{H}), 7.32(\mathrm{dd}, J=7.3,7.3 \mathrm{~Hz}, 1 \mathrm{H}, \mathrm{Ar}-\mathrm{H}), 7.24(\mathrm{~s}, 1 \mathrm{H}$, Ar-H), 7.29 (ddd, J = 7.4, 7.3, $1 \mathrm{~Hz}, 1 \mathrm{H}, \mathrm{Ar}-\mathrm{H}$ ), 7.02 (s, $1 \mathrm{H}, \mathrm{Ar}-\mathrm{H}$ ), 3.97 $\left(\mathrm{s}, 3 \mathrm{H}, \mathrm{ArOCH}_{3}\right), 3.94$ (s, $\left.3 \mathrm{H}, \mathrm{ArOCH}_{3}\right), 3.83$ (q, J = 7.4 Hz, CH), 1.48 (d, $\left.J=7.4 \mathrm{~Hz}, 3 \mathrm{H}, \mathrm{CH}_{3}\right)$.

$\left.{ }^{13} \mathrm{C} \mathrm{NMR} \mathrm{(} \mathrm{CDCl}_{3}, 100 \mathrm{MHz}\right): \delta=149.0$ (s, Ar-C), 148.9 (s, Ar-C), 148.7 (s, Ar-C), 141.5 (s, Ar-C), 140.8 (s, Ar-C), 132.8 (s, Ar-C), 126.8 (d, Ar$\mathrm{CH}), 125.6$ (d, Ar-CH), 123.7 (d, Ar-CH), 118.8 (d, Ar-CH), 107.3 (d, Ar$\mathrm{CH}), 103.0(\mathrm{~d}, \mathrm{Ar}-\mathrm{CH}), 56.1$ (q, $\left.\mathrm{ArOCH}_{3}\right), 56.0\left(\mathrm{q}, \mathrm{ArOCH}_{3}\right), 42.2(\mathrm{~d}, \mathrm{CH})$, $18.3\left(\mathrm{q}, \mathrm{CH}_{3}\right)$.

HRMS (APCI+): $m / z[M+H]^{+}$calcd for $\left[\mathrm{C}_{16} \mathrm{H}_{17} \mathrm{O}_{2}\right]^{+}: 241.1223$; found: 241.1209.

\section{2,7-Dimethoxy-9-methyl-9H-fluorene (8bf)}

In an oven-dried Schlenk tube, were added 2-bromophenylketone $\mathbf{5 b}$ (115 mg, $0.5 \mathrm{mmol})$, arylboronic acid $2 \mathbf{f}(84 \mathrm{mg}, 0.55 \mathrm{mmol}), \mathrm{Pd}(\mathrm{OAc})_{2}$ (5.6 mg, $5 \mathrm{~mol} \%$ ) and $\mathrm{K}_{2} \mathrm{CO}_{3}$ (138 mg, $1.0 \mathrm{mmol}$ ) followed by DMF at r.t. and the reaction mixture was stirred at $80^{\circ} \mathrm{C}$ for $20 \mathrm{~h}$. Then, to the cooled reaction mixture at ice temperature, was added $\mathrm{NaBH}_{4}(76 \mathrm{mg}$, $2 \mathrm{mmol}$ ) and stirring was continued at the same temperature for 0.5 h. After work-up, to the crude reaction mixture at ice temperature, were added DCE and $\mathrm{BF}_{3} \cdot \mathrm{OEt}_{2}(710 \mathrm{mg}, 5 \mathrm{mmol}$ ) and the mixture was stirred for $1 \mathrm{~h}$. Progress of the reaction for the formation of 2,7-dimethoxy-9-methyl-9H-fluorene $\mathbf{8 b f}$ was monitored by TLC. The reaction was then quenched with aq. $\mathrm{NaHCO}_{3}$, and the mixture was diluted with aq. $\mathrm{NH}_{4} \mathrm{Cl}$ and extracted with EtOAc $(3 \times 10 \mathrm{~mL})$. The combined organic layers were washed with saturated aq. $\mathrm{NaCl}$, dried $\left(\mathrm{Na}_{2} \mathrm{SO}_{4}\right)$, and filtered. Evaporation of the solvent under reduced pressure and purification of the crude material by silica gel column chromatography (petroleum ether/EtOAc, 99:1 to 95:5) furnished $\mathbf{8 b f}$.

Yield: $99 \mathrm{mg}$ (82\%); colourless solid; TLC (petroleum ether/EtOAc, 92:08; UV detection): $R_{f}=0.8$ (5b), 0.7 (8bf).

${ }^{1} \mathrm{H} \mathrm{NMR}\left(\mathrm{CDCl}_{3}, 400 \mathrm{MHz}\right): \delta=7.54(\mathrm{~d}, J=8.3 \mathrm{~Hz}, 2 \times 1 \mathrm{H}, \mathrm{Ar}-\mathrm{H}), 7.01$ (d, $J=2.1 \mathrm{~Hz}, 2 \times 1 \mathrm{H}, \mathrm{Ar}-\mathrm{H}$ ), 6.88 (dd, $J=8.3,2.4 \mathrm{~Hz}, 2 \times 1 \mathrm{H}, \mathrm{Ar}-\mathrm{H}$ ), $3.85\left(\mathrm{~s}, 2 \times 3 \mathrm{H}, \mathrm{ArOCH}_{3}\right), 3.90-3.84(\mathrm{~m}, 1 \mathrm{H}, \mathrm{CH}), 1.49$ (d, $J=7.4 \mathrm{~Hz}$, $\left.3 \mathrm{H}, \mathrm{CH}_{3}\right)$.

${ }^{13} \mathrm{C} \mathrm{NMR}\left(\mathrm{CDCl}_{3}, 100 \mathrm{MHz}\right): \delta=158.6(\mathrm{~s}, 2 \times \mathrm{Ar}-\mathrm{C}), 150.4(\mathrm{~s}, 2 \times \mathrm{Ar}-\mathrm{C})$, 133.5 (s, $2 \times \mathrm{Ar}-\mathrm{C}), 119.6$ (d, $2 \times \mathrm{Ar}-\mathrm{CH}), 112.6$ (d, $2 \times \mathrm{Ar}-\mathrm{CH}), 109.8$ (d, $2 \times \mathrm{Ar}-\mathrm{CH}), 55.5\left(\mathrm{q}, 2 \times \mathrm{ArOCH}_{3}\right), 42.5(\mathrm{~d}, \mathrm{CH}), 18.5\left(\mathrm{q}, \mathrm{CH}_{3}\right)$.

HRMS (APCI+): $m / z[M+H]^{+}$calcd for $\left[\mathrm{C}_{16} \mathrm{H}_{17} \mathrm{O}_{2}\right]^{+}: 241.1223$; found: 241.1229.

\section{2,3,7-Trimethoxy-9-methyl-9H-fluorene (8bg)}

In an oven-dried Schlenk tube, were added 2-bromophenylketone $\mathbf{5 b}$ (115 $\mathrm{mg}, 0.5 \mathrm{mmol}$ ), arylboronic acid $2 \mathrm{~g}(100 \mathrm{mg}, 0.55 \mathrm{mmol})$, $\mathrm{Pd}(\mathrm{OAc})_{2}\left(5.6 \mathrm{mg}, 5 \mathrm{~mol} \%\right.$ ) and $\mathrm{K}_{2} \mathrm{CO}_{3}(138 \mathrm{mg}, 1.0 \mathrm{mmol})$ followed by $\mathrm{DMF}$ at r.t. and the reaction mixture was stirred at $80^{\circ} \mathrm{C}$ for $20 \mathrm{~h}$. Then, to the cooled reaction mixture at ice temperature, was added $\mathrm{NaBH}_{4}$ (76 mg, $2 \mathrm{mmol}$ ) and stirring was continued at the same tem- perature for $0.5 \mathrm{~h}$. After work-up, to the crude reaction mixture at ice temperature, were added $\mathrm{DCE}$ and $\mathrm{BF}_{3} \cdot \mathrm{OEt}_{2}(710 \mathrm{mg}, 5 \mathrm{mmol})$ and stirring was continued for $1 \mathrm{~h}$. Progress of the reaction for the formation of 2,3,7-trimethoxy-9-methyl-9H-fluorene $\mathbf{8 b g}$ was monitored by TLC. The reaction was then quenched with aq. $\mathrm{NaHCO}_{3}$, and the mixture was diluted with aq. $\mathrm{NH}_{4} \mathrm{Cl}$ and extracted with EtOAc $(3 \times 10$ $\mathrm{mL}$ ). The combined organic layers were washed with saturated aq. $\mathrm{NaCl}$, dried $\left(\mathrm{Na}_{2} \mathrm{SO}_{4}\right)$ and filtered. Evaporation of the solvent under reduced pressure and purification of the crude material by silica gel column chromatography (petroleum ether/EtOAc, 99:1 to 92:8) furnished 8bg.

Yield: $116 \mathrm{mg}$ (85\%); colourless solid; TLC (petroleum ether/EtOAc, 92:08; UV detection): $R_{f}=0.7$ (5b), 0.4 (8bg).

${ }^{1} \mathrm{H} \mathrm{NMR}\left(\mathrm{CDCl}_{3}, 400 \mathrm{MHz}\right): \delta=7.50(\mathrm{~d}, J=8.3 \mathrm{~Hz}, 1 \mathrm{H}, \mathrm{Ar}-\mathrm{H}), 7.17(\mathrm{~s}$, $1 \mathrm{H}, \mathrm{Ar}-\mathrm{H}), 7.02$ (d, J = 2.2 Hz, $1 \mathrm{H}, \mathrm{Ar}-\mathrm{H}), 7.00$ (s, $1 \mathrm{H}, \mathrm{Ar}-\mathrm{H}), 6.87$ (dd, $J=8.3,2.3 \mathrm{~Hz}, 1 \mathrm{H}, \mathrm{Ar}-\mathrm{H}), 3.96\left(\mathrm{~s}, 3 \mathrm{H}, \mathrm{ArOCH}_{3}\right), 3.93\left(\mathrm{~s}, 3 \mathrm{H}, \mathrm{ArOCH}_{3}\right)$, $3.85\left(\mathrm{~s}, 3 \mathrm{H}, \mathrm{ArOCH}_{3}\right), 3.82$ (q, J = 7.4 Hz, $\left.1 \mathrm{H}, \mathrm{CH}\right), 1.48(\mathrm{~d}, J=7.4 \mathrm{~Hz}$, $\left.3 \mathrm{H}, \mathrm{CH}_{3}\right)$.

${ }^{13} \mathrm{C}$ NMR $\left(\mathrm{CDCl}_{3}, 100 \mathrm{MHz}\right): \delta=158.6(\mathrm{~s}, \mathrm{Ar}-\mathrm{C}), 150.9$ (s, $\left.\mathrm{Ar}-\mathrm{C}\right), 148.7$ (s, Ar-C), 148.1 (s, Ar-C), 140.8 (s, Ar-C), 133.8 (s, Ar-C), 133.0 (s, ArC), 119.3 (d, Ar-CH), 112.3 (d, Ar-CH), 110.0 (d, Ar-CH), 107.5 (d, Ar$\mathrm{CH}), 102.6(\mathrm{~d}, \mathrm{Ar}-\mathrm{CH}), 56.1\left(\mathrm{q}, \mathrm{ArOCH}_{3}\right), 56.1\left(\mathrm{q}, \mathrm{ArOCH}_{3}\right), 55.4$ (q, $\left.\mathrm{ArOCH}_{3}\right), 42.2(\mathrm{~d}, \mathrm{CH}), 18.4\left(\mathrm{q}, \mathrm{CH}_{3}\right)$.

HRMS (APCI+): $m / z[\mathrm{M}+\mathrm{H}]^{+}$calcd for $\left[\mathrm{C}_{17} \mathrm{H}_{19} \mathrm{O}_{3}\right]^{+}:$271.1329; found: 271.1324.

\section{9-Ethyl-2,3,7-trimethoxy-9H-fluorene (8cf)}

In an oven-dried Schlenk tube, were added 2-bromophenylketone $\mathbf{5 c}$ (137 mg, $0.5 \mathrm{mmol}$ ), arylboronic acid $\mathbf{2 f}(84 \mathrm{mg}, 0.55 \mathrm{mmol}), \mathrm{Pd}(\mathrm{OAc})_{2}$ (5.6 mg, $5 \mathrm{~mol} \%$ ) and $\mathrm{K}_{2} \mathrm{CO}_{3}(138 \mathrm{mg}, 1.0 \mathrm{mmol}$ ) followed by DMF at r.t. and the reaction mixture was stirred at $80^{\circ} \mathrm{C}$ for $20 \mathrm{~h}$. Then, to the cooled reaction mixture at ice temperature, was added $\mathrm{NaBH}_{4}(76 \mathrm{mg}$, $2 \mathrm{mmol}$ ) and the mixture was stirred at the same temperature for 0.5 h. After work-up, to the crude reaction mixture at ice temperature, were added $\mathrm{DCE}$ and $\mathrm{BF}_{3} \cdot \mathrm{OEt}_{2}(710 \mathrm{mg}, 5 \mathrm{mmol})$ and stirring was continued for $1 \mathrm{~h}$. Progress of the reaction for the formation of 9-ethyl2,3,7-trimethoxy-9H-fluorene 8 cf was monitored by TLC. The reaction was then quenched with aq. $\mathrm{NaHCO}_{3}$, and the mixture was diluted with aq. $\mathrm{NH}_{4} \mathrm{Cl}$ and extracted with EtOAc $(3 \times 10 \mathrm{~mL})$. The combined organic layers were washed with saturated aq. $\mathrm{NaCl}$, dried $\left(\mathrm{Na}_{2} \mathrm{SO}_{4}\right)$, and filtered. Evaporation of the solvent under reduced pressure and purification of the crude material by silica gel column chromatography (petroleum ether/EtOAc, 99:1 to 92:8) furnished 8cf.

Yield: $103 \mathrm{mg}$ (72\%); colourless solid; TLC (petroleum ether/EtOAc, 95:05; UV detection): $R_{f}=0.6$ (5c), $0.8(\mathbf{8 c f})$.

${ }^{1} \mathrm{H} \mathrm{NMR}\left(\mathrm{CDCl}_{3}, 400 \mathrm{MHz}\right): \delta=7.51(\mathrm{~d}, J=8.2 \mathrm{~Hz}, 1 \mathrm{H}, \mathrm{Ar}-\mathrm{H}), 7.16(\mathrm{~s}$, $1 \mathrm{H}, \mathrm{Ar}-\mathrm{H}$ ), 7.02 (d, J = $2.5 \mathrm{~Hz}, 1 \mathrm{H}, \mathrm{Ar}-\mathrm{H}$ ), 7.00 (s, $1 \mathrm{H}, \mathrm{Ar}-\mathrm{H}$ ), 6.88 (dd, $J=8.2,2.8 \mathrm{~Hz}, 1 \mathrm{H}, \mathrm{Ar}-\mathrm{H}), 3.96\left(\mathrm{~s}, 3 \mathrm{H}, \mathrm{ArOCH}_{3}\right), 3.93\left(\mathrm{~s}, 3 \mathrm{H}, \mathrm{ArOCH}_{3}\right)$, 3.91-3.84 (m, $1 \mathrm{H}, \mathrm{CH}), 3.85\left(\mathrm{~s}, 3 \mathrm{H}, \mathrm{ArOCH}_{3}\right), 2.10-1.99(\mathrm{~m}, 2 \mathrm{H}$, $\left.\mathrm{CH}_{2} \mathrm{CH}_{3}\right), 0.68\left(\mathrm{t}, \mathrm{J}=7.4 \mathrm{~Hz}, 3 \mathrm{H}, \mathrm{CH}_{2} \mathrm{CH}_{3}\right)$.

${ }^{13} \mathrm{C} \mathrm{NMR}\left(\mathrm{CDCl}_{3}, 100 \mathrm{MHz}\right): \delta=158.5$ (s, Ar-C), 149.1 (s, Ar-C), 148.7 (s, Ar-C), 148.0 (s, Ar-C), 139.0 (s, Ar-C), 134.7 (s, Ar-C), 133.9 (s, ArC), $119.2(\mathrm{~d}, \mathrm{Ar}-\mathrm{CH}), 112.3(\mathrm{~d}, \mathrm{Ar}-\mathrm{CH}), 110.4(\mathrm{~d}, \mathrm{Ar}-\mathrm{CH}), 107.8$ (d, Ar$\mathrm{CH}), 102.4(\mathrm{~d}, \mathrm{Ar}-\mathrm{CH}), 56.2\left(\mathrm{q}, \mathrm{ArOCH}_{3}\right), 56.1\left(\mathrm{q}, \mathrm{ArOCH}_{3}\right), 55.6$ (q, $\left.\mathrm{ArOCH}_{3}\right), 48.3(\mathrm{~d}, \mathrm{CH}), 25.8\left(\mathrm{t}, \mathrm{CH}_{2} \mathrm{CH}_{3}\right), 9.4\left(\mathrm{q}, \mathrm{CH}_{2} \mathrm{CH}_{3}\right)$.

HRMS (APCI+): $m / z[\mathrm{M}+\mathrm{H}]^{+}$calcd for $\left[\mathrm{C}_{18} \mathrm{H}_{21} \mathrm{O}_{3}\right]^{+}:$285.1485; found: 285.1466 . 


\section{2-Ethyl-9-phenyl-9H-fluorene (8ee)}

In an oven-dried Schlenk tube, were added 2-bromophenylketone $\mathbf{5 e}$ (131 mg, $0.5 \mathrm{mmol}$ ), arylboronic acid $\mathbf{2 f}\left(84 \mathrm{mg}, 0.55 \mathrm{mmol}\right.$ ), $\mathrm{Pd}(\mathrm{OAc})_{2}$ (5.6 mg, $5 \mathrm{~mol} \%$ ) and $\mathrm{K}_{2} \mathrm{CO}_{3}(138 \mathrm{mg}, 1.0 \mathrm{mmol}$ ) followed by DMF at r.t. and the reaction mixture was stirred at $80^{\circ} \mathrm{C}$ for $20 \mathrm{~h}$. Then, to the cooled reaction mixture at ice temperature, was added $\mathrm{NaBH}_{4}(76 \mathrm{mg}$, $2 \mathrm{mmol}$ ) and stirring was continued at the same temperature for 0.5 h. After work-up, to the crude reaction mixture at ice temperature, were added DCE and $\mathrm{BF}_{3} \cdot \mathrm{OEt}_{2}(710 \mathrm{mg}, 5 \mathrm{mmol}$ ) and stirring was continued for $1 \mathrm{~h}$. Progress of the reaction for the formation of 2-ethyl-9phenyl-9H-fluorene 8ee was monitored by TLC. The reaction was then quenched with aq. $\mathrm{NaHCO}_{3}$, and the mixture was diluted with aq. $\mathrm{NH}_{4} \mathrm{Cl}$ and extracted with EtOAc $(3 \times 10 \mathrm{~mL})$. The combined organic layers were washed with saturated aq. $\mathrm{NaCl}$, dried $\left(\mathrm{Na}_{2} \mathrm{SO}_{4}\right)$, and filtered. Evaporation of the solvent under reduced pressure and purification of the crude material by silica gel column chromatography (petroleum ether/EtOAc, 99:1 to 95:5) furnished 8ee.

Yield: $91 \mathrm{mg}$ (67\%); colourless solid; TLC (petroleum ether/EtOAc, 95:05; UV detection): $R_{f}=0.5$ (5e), 0.7 (8ee).

${ }^{1} \mathrm{H} \mathrm{NMR}\left(\mathrm{CDCl}_{3}, 400 \mathrm{MHz}\right): \delta=7.74(\mathrm{~d}, J=7.3 \mathrm{~Hz}, 1 \mathrm{H}, \mathrm{Ar}-\mathrm{H}), 7.69$ (d, $J=7.8 \mathrm{~Hz}, 1 \mathrm{H}, \mathrm{Ar}-\mathrm{H}), 7.34$ (dd, $J=7.3,7.3 \mathrm{~Hz}, 1 \mathrm{H}, \mathrm{Ar}-\mathrm{H}), 7.30-7.16$ (m, $6 \mathrm{H}, \mathrm{Ar}-\mathrm{H}), 7.14(\mathrm{~s}, 1 \mathrm{H}, \mathrm{Ar}-\mathrm{H}), 7.16-7.03(\mathrm{~m}, 2 \mathrm{H}, \mathrm{Ar}-\mathrm{H}), 4.99$ (s, $1 \mathrm{H}, \mathrm{CH}), 2.63\left(\mathrm{q}, J=7.8 \mathrm{~Hz}, 2 \mathrm{H}, \mathrm{CH}_{2} \mathrm{CH}_{3}\right), 1.20(\mathrm{t}, J=7.8 \mathrm{~Hz}, 3 \mathrm{H}$, $\mathrm{CH}_{2} \mathrm{CH}_{3}$ ).

${ }^{13} \mathrm{C}$ NMR $\left(\mathrm{CDCl}_{3}, 100 \mathrm{MHz}\right): \delta=148.2(\mathrm{~s}, \mathrm{Ar}-\mathrm{C}), 147.9(\mathrm{~s}, \mathrm{Ar}-\mathrm{C}), 143.8$ (s, Ar-C), 141.9 (s, Ar-C), 141.1 (s, Ar-C), 138.7 (s, Ar-C), 128.7 (d, 2C, $2 \times \mathrm{Ar}-\mathrm{CH}), 128.4$ (d, 2C, $2 \times \mathrm{Ar}-\mathrm{CH}), 127.3$ (d, $\mathrm{Ar}-\mathrm{CH}), 127.1$ (d, Ar-C), 126.9 (d, Ar-CH), 126.8 (d, Ar-CH), 125.3 (d, Ar-CH), 124.9 (d, Ar-CH), 119.7 (d, Ar-CH), 119.6 (d, Ar-CH), 54.4 (d, CH), 29.1 (t, $\left.\mathrm{CH}_{2} \mathrm{CH}_{3}\right), 15.9$ (q, $\left.\mathrm{CH}_{2} \mathrm{CH}_{3}\right)$.

HRMS (APCI+): $m / z\left[\mathrm{M}+\mathrm{NH}_{4}\right]^{+}$calcd for $\left[\mathrm{C}_{21} \mathrm{H}_{22} \mathrm{~N}\right]^{+}: 288.1747$; found: 288.1752 .

\section{2,3-Dimethoxy-9-phenyl-9H-fluorene (8eg)}

In an oven-dried Schlenk tube, were added 2-bromophenylketone $\mathbf{5 e}$ (131 $\mathrm{mg}, 0.5 \mathrm{mmol})$, arylboronic acid $2 \mathrm{~g}(100 \mathrm{mg}, 0.55 \mathrm{mmol})$, $\mathrm{Pd}(\mathrm{OAc})_{2}\left(5.6 \mathrm{mg}, 5 \mathrm{~mol} \%\right.$ ) and $\mathrm{K}_{2} \mathrm{CO}_{3}(138 \mathrm{mg}, 1.0 \mathrm{mmol})$ followed by DMF at r.t. and the reaction mixture stirred at $80{ }^{\circ} \mathrm{C}$ for $20 \mathrm{~h}$. Then, to the cooled reaction mixture at ice temperature, was added $\mathrm{NaBH}_{4}(76$ $\mathrm{mg}, 2 \mathrm{mmol}$ ) and stirring was continued at the same temperature for $0.5 \mathrm{~h}$. After work-up, to the crude reaction mixture at ice temperature, were added DCE and $\mathrm{BF}_{3} \cdot \mathrm{OEt}_{2}(710 \mathrm{mg}, 5 \mathrm{mmol})$ and stirring was continued for $1 \mathrm{~h}$. Progress of the reaction for the formation of 2,3dimethoxy-9-phenyl-9H-fluorene $8 \mathbf{e g}$ was monitored by TLC. The reaction was then quenched with aq. $\mathrm{NaHCO}_{3}$, and the mixture was diluted with aq. $\mathrm{NH}_{4} \mathrm{Cl}$ and extracted with EtOAc $(3 \times 10 \mathrm{~mL})$. The combined organic layers were washed with saturated aq. $\mathrm{NaCl}$, dried $\left(\mathrm{Na}_{2} \mathrm{SO}_{4}\right)$, and filtered. Evaporation of the solvent under reduced pressure and purification of the crude material by silica gel column chromatography (petroleum ether/EtOAc, 99:1 to 95:5) furnished 8eg.

Yield: $134 \mathrm{mg}$ (88\%); colourless solid; TLC (petroleum ether/EtOAc, 95:05; UV detection): $R_{f}=0.5$ (5e), 0.4 (8eg).

${ }^{1} \mathrm{H} \mathrm{NMR}\left(\mathrm{CDCl}_{3}, 400 \mathrm{MHz}\right): \delta=7.66$ (d, $\left.J=7.8 \mathrm{~Hz}, 1 \mathrm{H}, \mathrm{Ar}-\mathrm{H}\right), 7.33$ (dd, $J=7.3,7.3 \mathrm{~Hz}, 1 \mathrm{H}, \mathrm{Ar}-\mathrm{H}), 7.30-7.16(\mathrm{~m}, 5 \mathrm{H}, \mathrm{Ar}-\mathrm{H}), 7.16$ (dd, $J=7.3$, $7.3 \mathrm{~Hz}, 1 \mathrm{H}, \mathrm{Ar}-\mathrm{H}), 7.09$ (s, $1 \mathrm{H}, \mathrm{Ar}-\mathrm{H}), 7.08$ (d, $J=7.3 \mathrm{~Hz}, 1 \mathrm{H}, \mathrm{Ar}-\mathrm{H})$, $6.82(\mathrm{~s}, 1 \mathrm{H}, \mathrm{Ar}-\mathrm{H}), 4.93(\mathrm{~s}, 1 \mathrm{H}, \mathrm{CH}), 3.99\left(\mathrm{~s}, 3 \mathrm{H}, \mathrm{ArOCH}_{3}\right), 3.81(\mathrm{~s}, 3 \mathrm{H}$, $\left.\mathrm{ArOCH}_{3}\right)$.

$\left.{ }^{13} \mathrm{C} \mathrm{NMR} \mathrm{(} \mathrm{CDCl}_{3}, 100 \mathrm{MHz}\right): \delta=149.2$ (s, Ar-C), 149.1 (s, Ar-C), 148.1 (s, Ar-C), 141.7 (s, Ar-C), 141.2 (s, Ar-C), 140.3 (s, Ar-C), 133.6 (s, ArC), 128.7 (d, 2C, $2 \times \mathrm{Ar}-\mathrm{CH}), 128.2$ (d, 2C, $2 \times \mathrm{Ar}-\mathrm{CH}), 127.2$ (d, Ar-C),
126.8 (d, Ar-CH), 126.0 (d, Ar-CH), 125.0 (d, Ar-CH), 118.7 (d, Ar-CH), 108.3 (d, Ar-CH), 102.8 (d, Ar-CH), 56.1 (q, $\mathrm{ArOCH}_{3}$ ), 56.0 (q, $\mathrm{ArOCH}_{3}$ ), $54.3(\mathrm{~d}, \mathrm{CH})$.

HRMS (APCI+): $m / z[\mathrm{M}+\mathrm{H}]^{+}$calcd for $\left[\mathrm{C}_{21} \mathrm{H}_{19} \mathrm{O}_{2}\right]^{+}: 303.1380$; found: 303.1361.

\section{Funding Information}

We are grateful to the Department of Science and Technology-Science and Engineering Research Board (DST-SERB) [NO.:SB/S1/OC-39/2014], New Delhi, for the financial support. D. R. K. and D. R. K. thank UGC, New Delhi, for the award of Research Fellowships.

\section{Supporting Information}

Supporting information for this article is available online at https://doi.org/10.1055/s-0037-1610663.

\section{References}

(1) (a) Tietze, L. F. Chem. Rev. 1996, 96, 115. (b) Tietze, L. F.; Beifuss, U. Angew. Chem. 1993, 105, 137. (c) Kishi, Y. Pure Appl. Chem. 1993, 65, 771. (d) Suh, E. M.; Kishi, Y. J. Am. Chem. Soc. 1994, $116,11205$.

(2) (a) Capodilupo, A.; Vergaro, V.; Accorsi, G.; Fabiano, E.; Baldassarre, F.; Anna, G.; Gigli, G.; Ciccarella, G. Tetrahedron 2016, 72, 2920. (b) Chi, S.; Li, L.; Wu, Y. J. Phys. Chem. 2016, 120, 13706. (c) Tian, X.; Ren, F.; Zhao, B.; Ren, Y.; Zhao, S.; Wang, J. Catal. Commun. 2018, 106, 44. (d) Thangadurai, D.; Nithya, I.; Manjubaashini, N.; Bhuvanesh, N.; Bharathi, G.; Nandhakumar, R.; Nataraj, D. Spectrochim. Acta, Part A. 2018, 465.

(3) Shi, Y.; Gao, S. Tetrahedron 2016, 1717.

(4) (a) Okpekon, T.; Millot, M.; Champy, P.; Gleye, C.; Yolou, S.; Bories, C.; Loiseau, P.; Laurens, A.; Hocquemiller, R. Nat. Prod. Res. 2009, 23, 909. (b) Fu, J.-M.; Zhao, B.-P.; Sharp, M.; Snieckus, V. Can. J. Chem. 1994, 72, 227. (c) Cone, M. C.; Melville, C. R.; Gore, M. P.; Gould, S. J.J. Org. Chem. 1993, 58, 1058. (d) Nicolaou, K.; Hale, C. R.; Nilewski, C.; Ioannidou, H. A. Chem. Soc. Rev. 2012, 41, 5185. (e) Fieser, L. F.; Fieser, M. Natural Products Related To Phenanthrene. 3rd. Ed.; Reinhold Publishing Corporation: New York, 1949.

(5) (a) Barluenga, J.; Trincado, M.; Rubio, E.; González, J. M. Angew. Chem. Int. Ed. 2006, 45, 3140. (b) Fukuyama, T.; Maetani, S.; Miyagawa, K.; Ryu, I. Org. Lett. 2014, 16, 3216. (c) Nösel, P.; Moghimi, S.; Hendrich, C.; Haupt, M.; Rudolph, M.; Rominger, F.; Hashmia, A. S. K. Adv. Synth. Catal. 2014, 356, 3755. (d) Chen, X. Y.; Ozturk, S.; Sorensen, E. J. Org. Lett. 2017, 19, 1140. (e) Wertz, S.; Leifert, D.; Studer, A. Org. Lett. 2013, 15, 928. (f) Laha, J. K.; Jethava, K. P.; Patel, S. Org. Lett. 2015, 17, 5890. (g) Prashad, M.; Liu, Y.; Mak, X. Y.; Har, D.; Repič, O.; Blacklock, T. J. Tetrahedron Lett. 2002, 43, 8559. (h) Gao, Q.; Xu, S. Org. Biomol. Chem. 2018, 16, 208. (i) Fukuyama, T.; Maetani, S.; Miyagawa, K.; Ryu, I. Org. Lett. 2014, 16, 3216. (j) Liu, T.-P.; Liao, Y.-X.; Xing, C.-H.; Hu, Q.-S. Org. Lett. 2011, 13, 2452.

(6) (a) Hwang, S. J.; Cho, S. H.; Chang, S. J. Am. Chem. Soc. 2008, 130, 16158. (b) Rathore, R.; Chebny, V. J.; Abdelwahed, S. H. J. Am. Chem. Soc. 2005, 127, 8012. (c) Chiang, C.-L.; Shu, C.-F.; Chen, C.T. Org. Lett. 2005, 7, 3717. (d) Romain, M.; Tondelier, D.; Vanel, J. C.; Geffroy, B.; Jeannin, O.; Rault-Berthelot, J.; Métivier, R.; Poriel, C. Angew. Chem. Int. Ed. 2013, 52, 14147. (e) Sarkar, S.; 
Maiti, S.; Bera, K.; Jalal, S.; Jana, U. Tetrahedron Lett. 2012, 53, 5544. (f) Chandrasekhar, V.; Suriya Narayanan, R.; Thilagar, P. Organometallics 2009, 28, 5883. (g) Shen, X.; Gu, N.; Liu, P.; Ma, X.; Xie, J.; Liu, Y.; He, L.; Dai, B. RSC Adv. 2015, 5, 63726.

(7) (a) Mishra, K.; Pandey, A. K.; Singh, J. B.; Singh, R. M. Org. Biomol. Chem. 2016, 14, 6328. (b) Tang, J.; Zhao, S.; Wei, Y.; Quan, Z.; Huo, C. Org. Biomol. Chem. 2017, 15, 1589.

(8) (a) Gandeepan, P.; Hung, C.-H.; Cheng, C.-H. Chem. Commun. 2012, 9379. (b) Li, H.; Zhu, R.-Y.; Shi, W.-J.; He, K.-H.; Shi, Z.-J. Org. Lett. 2012, 14, 4850. (c) Wan, J.-C.; Huang, J.-M.; Jhan, Y.-H.; Hsieh, J.-C. Org. Lett. 2013, 15, 2742.

(9) (a) Campo, M. A.; Larock, R. C. J. Org. Chem. 2002, 67, 5616. (b) Furusawa, T.; Morimoto, T.; Oka, N.; Tanimoto, H.; Nishiyama, Y.; Kakiuchi, K. Chem. Lett. 2016, 45, 406.

(10) Pünner, F.; Schieven, J.; Hilt, G. Org. Lett. 2013, 15, 4888.

(11) (a) Reddy, P. V.; Karegoudar, T.; Monisha, T.; Nayak, A. S. Int. Biodeterior. Biodegrad. 2017, 123, 156. (b) George, S. R.; Elton, T. E.; Harper, J. B. Org. Biomol. Chem. 2015, 13, 10745.

(12) (a) Sreenivasulu, C.; Reddy, A. G. K.; Satyanarayana, G. Org. Chem. Front. 2017, 4, 972. (b) Das, A.; Gopi Krishna Reddy, A.; Satyanarayana, G. RSC Adv. 2014, 4, 26662. (c) Ramulu, B. V.; Satyanarayana, G. RSC Adv. 2015, 5, 70972. (d) Krishna, J.; Niharika, P.; Satyanarayana, G. RSC Adv. 2015, 5, 26749. (e) Mahendar, L.; Satyanarayana, G. RSC Adv. 2016, 6, 20588.

(13) Liu, Z.; Tan, H.; Wang, L.; Fu, T.; Xia, Y.; Zhang, Y.; Wang, J. Angew. Chem. 2015, 127, 3099 .

(14) Das, T.; Chakraborty, A.; Sarkar, A. Tetrahedron Lett. 2014, 55, 5174.
(15) (a) Reddy, A. G. K.; Satyanarayana, G. J. Org. Chem. 2016, 81, 12212. (b) Niharika, P.; Ramulu, B. V.; Satyanarayana, G. ACS Omega 2018, 3, 218. (c) Suchand, B.; Satyanarayana, G. J. Org. Chem. 2016, 81, 6409. (d) Suchand, B.; Satyanarayana, G. Eur. J. Org. Chem. 2018, 2233. (e) Sreenivasulu, C.; Satyanarayana, G. Eur. J. Org. Chem. 2018, 2846.

(16) (a) Ravi Kumar, D.; Satyanarayana, G. Org. Lett. 2015, 17, 5894. (b) Kumar, D. R.; Satyanarayana, G. ChemistrySelect 2018, 3, 7867.

(17) Ramulu, B. V.; Reddy, A. G. K.; Satyanarayana, G. Synlett 2013, $24,868$.

(18) Niharika, P.; Ramulu, B. V.; Satyanarayana, G. Org. Biomol. Chem. 2014, 12, 4347.

(19) Niharika, P.; Satyanarayana, G. Eur. J. Org. Chem. 2018, 971.

(20) (a) Rana, N.; Niharika, P.; Kishore, D. R.; Satyanarayana, G. ChemistrySelect 2017, 2, 10809. (b) Reddy, A. G. K.; Krishna, J.; Satyanarayana, G. ChemistrySelect 2016, 1, 1151.

(21) (a) Guijie, L.; Erjuan, W.; Haoyi, C.; Hongfeng, L.; Yuanhong, L.; Peng, G. W. Tetrahedron 2008, 64, 9033. (b) Konishi, H.; Futamata, S.; Wang, X.; Manabe, K. Adv. Synth. Catal. 2018, 360, 1805. (c) Ciske, F. L.; Jones, W. D. Jr. Synthesis 1998, 1195. (d) Liu, L.; Wang, F.; Li, Z.; Wang, J. Asian J. Org. Chem. 2014, 3, 695. (e) Corrie, T. J.; Ball, L. T.; Russell, C. A.; Lloyd-Jones, G. C. J.Am. Chem. Soc. 2016, 139, 245. (f) Klemm, L. H.; Huber, E.; Klopfenstein, C. E. J. Org. Chem. 1964, 29, 1960. (g) Sarkar, S.; Tadigoppula, N. RSC Adv. 2014, 4, 40964. (h) Zhao, J.; Yue, D.; Campo, M. A.; Larock, R. C. J. Am. Chem. Soc. 2007, 129, 5288. 